\title{
Changes in Ammonium and pH within Intertidal Sediments in Relation to Temperature and the Occurrence of Non-Indigenous Bivalves
}

\author{
Leah I. Bendell, Kayi Chan, Sophie Crevecoeur, Charlotta Prigent \\ Department of Biological Sciences, Simon Fraser University, Burnaby, Canada \\ Email: bendell@sfu.ca
}

Received 15 April 2014; revised 17 May 2014; accepted 12 June 2014

Copyright (C) 2014 by authors and Scientific Research Publishing Inc. This work is licensed under the Creative Commons Attribution International License (CC BY). http://creativecommons.org/licenses/by/4.0/

(c) (i) Open Access

\begin{abstract}
Our objective was to determine the role of two invasive bivalves on the concentration of ammonium as well as pH within intertidal surface sediments (0 - 3 and $3-6 \mathrm{~cm}$ depth) and interstitial waters, within the context of a warming environment. To meet this objective we applied both controlled laboratory (microcosm) and field (mesocosm) experiments where we varied bivalve presence and absence and sediment temperature. Mesocosm sampling was tide dependent as we attempted to capture changes in ammonium concentration and $\mathrm{pH}$ as related to flood and ebb tide. We focused on ammonium as this nutrient is typically a limiting nutrient in oceanic systems and its cycling is a key process that regulates biological productivity. We also determined pH because of the increasing threat of ocean acidification. Integration of laboratory and field studies suggests that bivalves significantly contribute to ammonium to the intertidal with this amount increasing with increasing temperature. This ammonium is then released from the sediment as a "pulse" to overlying seawater on the flood tide. Under laboratory conditions, increased temperature and density of bivalves decreased overlying water $\mathrm{pH}$. Mesocosm studies suggested some tide dependence of $\mathrm{pH}$ with flood tide acting as a buffer, increasing $\mathrm{pH}$ on the flood tide, after sediment exposure during ebb tide. Increased numbers of invasive bivalves within a warming environment are likely to increase amounts of ammonium released as a pulse on flood tides from intertidal ecosystems making this region a source of ammonium to coastal seas. Greater numbers of non-indigenous bivalves within the intertidal could also contribute to increased acidity within these regions although the significance of such increases is unknown.
\end{abstract}

\section{Keywords}

Non-Indigenous Bivalves, Temperature, Intertidal, Ammonium, Flood Tide 


\section{Introduction}

The shallow seas of coastal zones are one of the most valued of the world's ecosystems ranking higher than terrestrial or open ocean systems despite their smaller area, a result of their role in the storage and cycling of the nutrients nitrogen and phosphorus [1]. A number of studies have demonstrated the strong control that benthic invertebrates have on the cycling of nutrients within this region and depending on their abundances and distribution can be the primary influencing factor for essential nutrients (e.g., [2]). This has been especially demonstrated for bivalves, such as oysters, mussels and clams which when in high abundances can be the major determinants of the fate of nutrients notably nitrogen within the intertidal [2] [3]. Anthropogenic related activities that increase the bivalve community relative to other members of the intertidal community could affect nutrient cycling within this region which in turn could influence the supply of key nutrients to coastal seas. Increases in intertidal surface temperatures due to climate change will also affect the rates of these cycles.

On the west coast of British Columbia (BC), the intertidal bivalve community is changing due to the intentional introduction of the Manila clam (Venerupis philippinarum) for farming purposes and the non-intentional introduction of the varnish clam (Nuttalia obscurata). Both species are non-indigenous and are now the dominant bivalves replacing the indigenous littleneck clam (Leukoma staminea) which is confamilial to the Manila clam [4] and of similar size to the varnish clam. Manila clams were first found in BC in Ladysmith Harbour in 1936. In 30 years they spread throughout the Strait of Georgia and along the entire western coast of Vancouver Island and have become one of the major intertidal bivalves [4]. In contrast to the intentional introduction of the Manila is the non-intentional spread of the highly invasive varnish clam. First reported in the early 1990s, the varnish clam, native to China and Korea, is thought to have been transported in ballast waters to Vancouver Harbour and has since spread to a northern limit in Smith Sound, BC and to Coos Bay, Oregon in the south [5]. This species can reach densities of $800 \mathrm{~m}^{-2}$, up to four times greater than those of indigenous species [6]

High densities of the bivalve Austrovenus stutchburyi have been shown to increase ammonium efflux from sediments by an order of magnitude with this bivalve regenerated ammonium possibly supporting pelagic primary production previously limited by the availability of inorganic nitrogen, i.e., sediments became a net source rather than sink for ammonium to coastal seas [2]. Understanding the role that non-indigenous species play in influencing geochemical cycles (i.e., whether intertidal sediments are net sources or sinks for key nutrients) will therefore be necessary to determine their potential impact on primary and thereby secondary productivity within shallow coastal seas. This is of particular concern for coastal BC where the Manila and varnish clams are now the dominate bivalves within the intertidal and therefore will have the greatest impact on nutrient cycles within this region.

Thus the overall objective of our study is to contribute to a better understanding of how changes in community composition with respect to increased abundances of two non-indigenous bivalves in relation to increased temperature, alter ammonium concentrations within the intertidal. To meet this objective we applied both controlled laboratory microcosm and field mesocosm studies where we manipulated temperature and the presence and absence of bivalves. In addition to ammonium and given the ever increasing concern of ocean acidification we also measured $\mathrm{pH}$. Over the next century, increased concentrations of atmospheric $\mathrm{CO}_{2}$ are expected to cause a reduction in oceanic $\mathrm{pH}$ of $0.3-0.4 \mathrm{pH}$ units, which in turn will significantly negatively impact bivalves of both economic and ecological importance [7]. Of concern are the large gaps in our understanding of the impacts of ocean acidification which includes the natural variability of $\mathrm{pH}$ and the interactions with changes of other environmental stressors such as increased temperature [7]. It is hoped therefore that outcomes of our study will help better predict the impacts that non-indigenous species and climate change will have within the intertidal with respect to ammonium and $\mathrm{pH}$ such that we can better manage these regions and the ecological services they provide.

\section{Materials and Methods}

Sediments were collected from and field research was conducted at Fillongley Provincial Park on Denman Island, BC (49 $\left.31^{\prime} 59^{\prime \prime} \mathrm{N}, 124^{\circ} 49^{\prime} 0^{\prime \prime} \mathrm{W}\right)$. Sediment characteristics (grain size, organic matter content (\%LOI) and iron) are provided in [8] and Chan and Bendell [6]. As both the Manila and varnish clam are occurring in increased numbers within the intertidal regions of BCs Pacific west coast, we used Manila clams for the experimental tide experiments and varnish clams for the ambient heating and field experiments. As our objectives were to assess the role of the non-indigenous bivalves in altering sediment $\mathrm{pH}$ and ammonium, prior to experi- 
mental manipulation, all sediments were wet sieved (2 mm) using seawater to homogenize and remove all other benthic invertebrates (of greater than $2 \mathrm{~mm}$ in size).

\subsection{Microcosm Studies}

\subsubsection{Ambient Heating}

All treatments and controls were replicated three times for a total of 12 microcosms and were randomly assigned as; 3 sterilized sediment/no clams, 3 sterilized sediment/with clams, 3 non-sterilized sediment/no clams, 3 nonsterilized sediment/with clams. Sediments used for the microcosm experiments were sterilized by autoclaving twice at $121^{\circ} \mathrm{C}$ for an hour [9]. Seawater collected from Fillongely Park was filtered and autoclaved once for 30 minutes and allowed to settle for 24 hours prior to use [10]. Sediments and seawater for the unsterilized treatments were left untreated.

Plastic containers $(10 \mathrm{~cm} * 10 \mathrm{~cm} * 10 \mathrm{~cm})$ were used as microcosms and were filled with approximately 500 grams of sediment and $250 \mathrm{~mL}$ of seawater. Treatment microcosms contained 3 varnish clams for a stocking density of $3 / 100 \mathrm{~cm}^{2}$ or $300 / \mathrm{m}^{2}$ which represents densities observed under field conditions [6] [8]. All microcosms were aerated with air stones and pumps to ensure oxic conditions within surficial sediments (as in natural tidal substrates) necessary for nitrification [11]. Microcosms were set-up in a temperature controlled room and allowed to equilibrate for 24 hours before the start of the experiment. After 24 hours, the first sediment and overlying water samples were taken before the addition of varnish clams (purchased locally and acclimatized at $15^{\circ} \mathrm{C}$ for a week prior to experimentation) to each of the treatment microcosms. Microcosm experiments were conducted at an initial room temperature setting of $15^{\circ} \mathrm{C}$ (i.e., the average temperature for June when sediments and water were collected, National Climate Data and Information Archive for the Comox A station) and after 7 days, warmed to approximately $20^{\circ} \mathrm{C}$ over a period of 5 days. Ambient room temperature was then reset to $15^{\circ} \mathrm{C}$ with cooling occurring over the remaining 10 days of the experiment. The experiment was conducted for 22 days with sampling occurring every two days. No food was added to the varnish clam microcosms as varnish clams are both suspension and deposit feeders and food would have been obtained from the organic content of sediment which was approximately $6 \mathrm{mg} \cdot \mathrm{g}^{-1}$ [8]. At time of sampling, triplicate samples of surficial sediment (approximately 2 - 3 grams) was gently removed by plastic spoon, placed into plastic Ziplock ${ }^{\circledR}$ bags and frozen until analysis. Triplicate samples of $5 \mathrm{mLs}$ each of overlying water were removed by syringe, placed into clean glass vials and frozen until analysis (freezing has been shown to be an effective way of stabilizing ammonium concentrations in samples that cannot be analyzed immediately [12] Overlying waters were replenished to the initial volume of $250 \mathrm{~mL}$ after sampling. Sediments were homogenized by thoroughly shaking sediments in their plastic bags before subsamples were taken for ammonium analyses.

\subsubsection{Experimental Tidal Cycle}

Locally purchased Manila clams were used in the experiments and acclimatized for one week at $12^{\circ} \mathrm{C}$ prior to manipulation. Twelve plastic containers $(14 \mathrm{~cm}$ length $\times 10 \mathrm{~cm}$ depth $\times 10 \mathrm{~cm}$ width) used for microcosms were established in a cold room at $12^{\circ} \mathrm{C}$ to which 800 grams of sediments and $500 \mathrm{~mL}$ of seawater were added. Each microcosm was constantly aerated with air stones and pumps throughout the experiments. Treatments were randomly assigned to the 12 microcosms. Two factors were varied, temperature and the absence and presence of bivalves (3 per treatment), for 4 treatments * 3 replicates; $12^{\circ} \mathrm{C} /$ no bivalves, $12^{\circ} \mathrm{C} /$ bivalves, $20^{\circ} \mathrm{C} /$ no bivalves, $20^{\circ} \mathrm{C} /$ bivalves. To mimic intense warming events where the intertidal surficial sediments can reach temperatures of $40^{\circ} \mathrm{C}$, sediment temperature was maintained by direct heating with heat lamp as was done under field conditions. To simulate tidal conditions, after acclimation, overlying water was drained from the microcosm, the sediment directly heated for 8 hours, then seawater replaced for 16 hrs. This was repeated three times to obtain an experimental tidal cycle with triplicate sediment and water samples taken as indicated in Figure 1 where EXPI, II, III refer to the three times sediments were sampled after heating for 8 hours, FI, II and III are the three times when sediment and seawater was sampled post flooding and exposure, and RI, II and III are the three times when sediment and seawater was sampled after sediment was covered with seawater for 16 hours.

\subsubsection{Mesocosm Studies}

Nine mesocosms $(1.0 \mathrm{~m}$ width $\times 1.0 \mathrm{~m}$ length $\times 0.3 \mathrm{~m}$ depth, comprised of PVC pipe frames and $3 \mathrm{~mm}$ plastic mesh) used for previous experiments that were conducted two years prior to the current experiments [6] were 


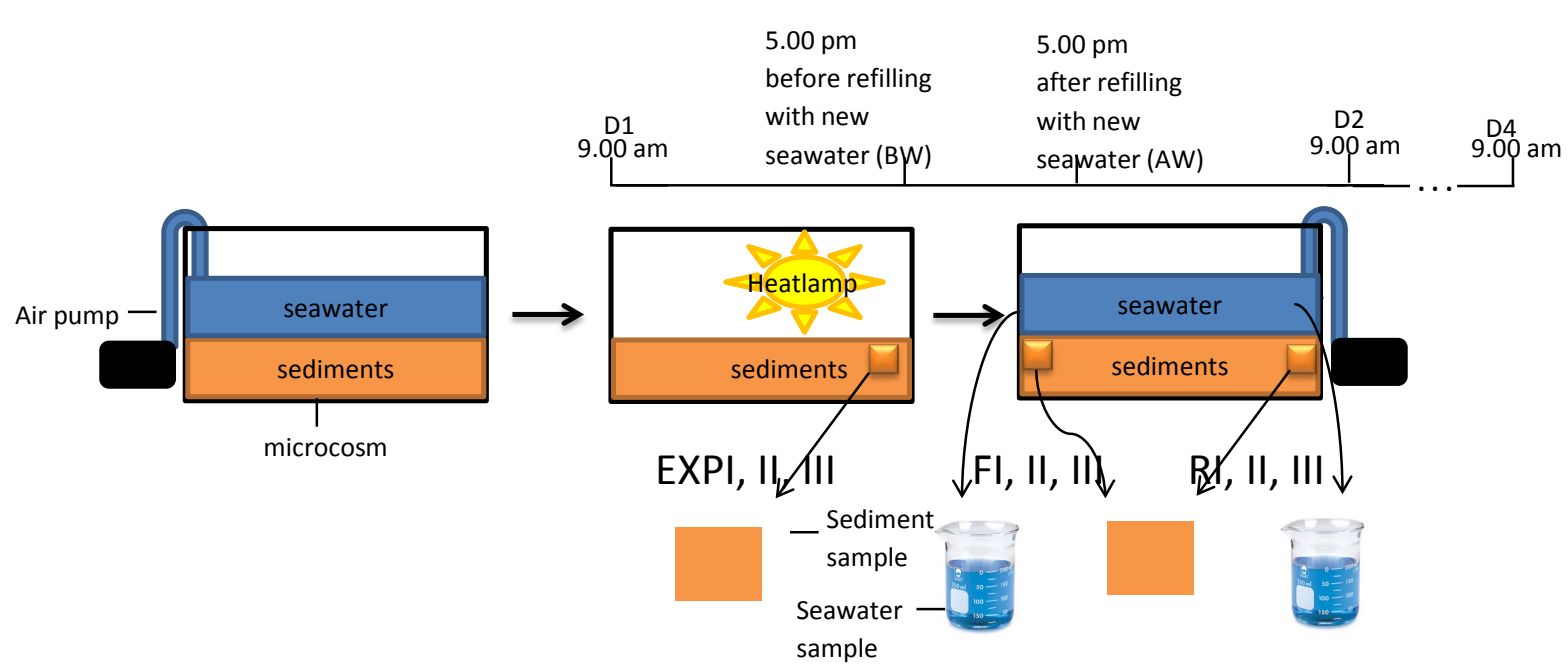

Figure 1. Experimental design for the experimental tidal cycle. EXP are samples taken after 8 hours exposure to heat lamps, $\mathrm{F}$ are those taken just after being inundated and $\mathrm{R}$ is just after overlying waters are removed (see also text).

again employed for experimental manipulation. Further details on mesocosm design and set-up are described in [13]. Sediment geochemistry (grain size, organic matter and iron) can be found in [6] [8]. The benthic invertebrate community within each mesocosm had been previously removed allowing for manipulation of just the number of bivalves. Within the centre of each mesocosm a $0.25 \mathrm{~m}^{2}$ region was established and seeded with 50 varnish clams of 20 - $35 \mathrm{~mm}$ length (for a density of $200 / \mathrm{m}^{2}$, the average density of bivalves within the intertidal of Lambert Channel where the mesocosms were deployed [6]). Each mesocosm was supplied with an interstitial water sampler (IWS) which consisted of a PVC pipe $10 \mathrm{~cm}$ length and $2.5 \mathrm{~cm}$ width which had two sampling ports at 3 and $6 \mathrm{~cm}$ depth connected to the surface with tubing (after [14]). IWS's were inserted into the sediment with the tubing extruding from the surface of the sediment to allow for sampling. To achieve differences in surficial sediment temperature, triplicate mesocosms were randomly assigned one of three treatments; 3 exposed (no temperature manipulation), 3 covered to prevent natural heating and hence warming, and 3 heated. Covered plots were covered with a Mylar sheet which reflected $97 \%$ of radiated heat (Space Blanket ${ }^{\circledR}$ ). Heated plots were radiated for one-two hours during low tide with an electric heat lamp supported by a Honda ${ }^{\circledR}$ generator.

Sediments and interstitial water were sampled in triplicate just as the tide covered and inundated each of the mesocosms inclusive of sediments and again just as the mesocosms became exposed. In this way we hoped to capture the "pulse" of nutrients associated with the time the intertidal was inundated and when it was exposed. Ten mLs of interstitial water was extracted by syringe from the IWS's at 3 and $6 \mathrm{~cm}$ depth within the sediment, placed into clean glass vials with minimal headspace, tightly capped then placed on ice in a cooler until analysis for $\mathrm{pH}$ and ammonium (within ten minutes of sampling). Sediment cores were taken randomly from each plot just before tide inundation (flood tide) and just after (ebb tide) by coring to a depth of $10 \mathrm{~cm}$ with a $50 \mathrm{~mL}$ Falcon tube ${ }^{\circledR}$ with the end removed to allow for sediment removal. Sediments were transfer to labelled Ziploc ${ }^{\circledR}$ bags and frozen until analysis. Prior to ammonium analyses, frozen sediments were thawed and sectioned into 0 - $3 \mathrm{~cm}$ (surface) and $3-6 \mathrm{~cm}$ (sub-surface) depths. A temperature probe was inserted into the sediment to a depth of $3 \mathrm{~cm}$ in the right corner of each mesocosm and temperature recorded every hour during the time that the intertidal was exposed. Initial temperatures were subtracted from final temperatures and differences expressed as delta T (Figure 2(a) and Figure 2(b)). We followed three tide cycles (3 days), with RI, RII and RIII representing receding tides on Day I, II and III and FI, FII and FIII representing flood tides on Day I, II and III. There was a rain event (accumulation of $2 \mathrm{~mm}$, National Climate Data and Information Archive for the Comox A station) between FII and RIII (as tide was flooding).

\section{Sample Analysis; Microcosm and Mesocosm Water and Sediment Samples}

\section{1. $\mathrm{pH}$}

pH was measured by a portable field $\mathrm{pH}$ meter calibrated by a pH 4 and 7 buffer. 
SEDIMENT TEMPERATURE

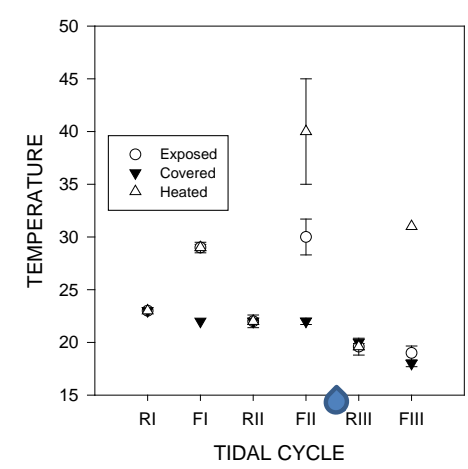

(a)

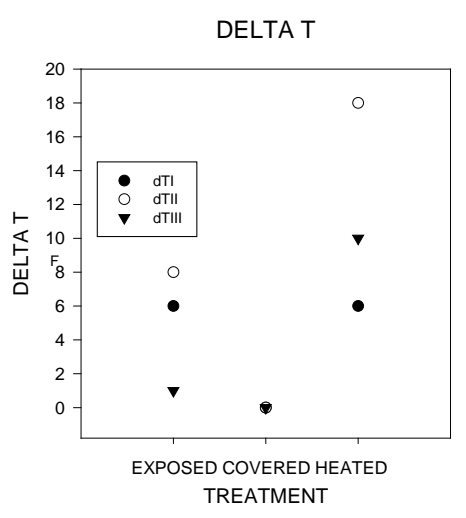

(b)

Figure 2. (a) Differences in intertidal sediment temperature achieved through the three treatments, exposed (no manipulation), covered (covered with a reflective cover) and heated (direct heating for 1 - 2 hrs); (b) Delta $\mathrm{T}$ is the change in temperature at depth of $3 \mathrm{~cm}$ within the sediment over the period of tide exposure, initial temperature subtracted from final temperature. $\mathrm{F}$ is flood tide, $\mathrm{R}$ is receding tide. Values in (a) are averages with standard errors (sample sizes reported within text). The rain event is indicated as a blue rain drop between FII and RIII.

\subsection{Ammonium-Sediment}

Ammonium concentration was determined using the indophenol blue method as described in [15]. Approximately $1 \mathrm{~g}$ of wet sediment was mixed with $10 \mathrm{mLs}$ of $2 \mathrm{M}$ of potassium chloride and shaken on a mechanical shaker for an hour. After sediments had settled, the supernatant was filtered through Whatman no.42 filter paper and stored in the fridge $\left(\sim 4^{\circ} \mathrm{C}\right)$ until analysis could be performed. $0.5 \mathrm{~mL}$ of the supernatant was combined with EDTA, phenol-nitroprusside and buffer solutions and diluted with double de-ionized water $\left(\mathrm{ddH}_{2} \mathrm{O}\right)$ for a total volume of $2.5 \mathrm{~mL}$. Samples were placed in a water bath $\left(40^{\circ} \mathrm{C}\right)$ for 30 minutes, cooled to room temperature and read on a spectrophotometer at $636 \mathrm{~nm}$. Ammonium concentrations of samples were determined from a calibration curves created from a set of known standards $\left(0.001,0.01\right.$ and $\left.0.1 \mu \mathrm{g} \cdot \mathrm{g}^{-1}\right)$ and values converted to $\mu \mathrm{g} \cdot \mathrm{g}^{-1}$.

\subsection{Ammonium-Water}

Ammonium was determined by ammonium ion-selective electrode (ISE), an Oakton ${ }^{\circledR}$ Acorn TM series Ion 6 electrode calibrated with standards (after Bendell-Young et al. 2010). Standards were made with seawater to account for background interferences due to the high conductivity of seawater. Because background seawater concentrations were different for each set of experiments (seawater used for the experimental tidal cycle was from a local inlet, whereas seawater for the ambient heating and field experiments was from Fillongley Park) determined aqueous ammonium values can be compared within each experiment but not among. Ammonium concentrations of samples were determined from calibration curves created from a set of known standards (0.1, 0.01 and $0.001 \mu$ moles $\cdot \mathrm{L}^{-1}$ ) and values expressed in $\mu \mathrm{M}$. For both microcosm and mesocosm experiments the ammonium probe was calibrated each day to the set of known standards.

\subsection{Statistical Analysis}

All analysis was implemented through Systat (Sigma Plot 12.5). Data were checked for normality and equal variances; if assumptions were not met, data were log transformed prior to analyses. For the ambient warming experiments, the sorption co-efficient (Kd) was calculated as sediment ammonium concentration $\left(\mathrm{mg} \cdot \mathrm{g}^{-1}\right) /(\mathrm{ammo}-$ nium concentration in the overlying water) $\left(\mathrm{mg} \cdot \mathrm{L}^{-1}\right)$. Ambient warming experiments were analyzed through repeated measures two-way ANOVA with treatment and time as the two variables whereas experimental tidal cycle and mesocosm studies were analyzed by three-way ANOVA with Day, Tide and Treatment as the three variables. Acceptance of statistical significance was at 0.05 , however, those values $>0.05$ and $<0.09$ are provided as indicators of "trends". 


\section{Results}

\subsection{Ambient Room Temperature}

Varnish clams excrete ammonium directly as inorganic ammonium through urine of which the composition can range from $60 \%-100 \%$ ammonium depending on the species of bivalve [16] and indirectly as organic ammonium (feces and psuedofeces) to the water and sediment environment. The pool of ammonium within the sediment and overlying water will be determined by the rate of ammonification of the organic pool and the rate of nitrification of the inorganic pool. Ammonification will increase the pool, nitrification will decrease the pool. Sterilization of sediments should remove bacterial activity required for ammonification and nitrification. Therefore, concentrations of ammonium measured in sediments and water in the sterilized treatments should be from the bivalve alone rather than that contributed by ammonification or lost through nitrification. Both sterilization and the presence or absence of clams significantly affected sediment and water ammonium (Table 1). Treatments

Table 1. Significant sources of variation for the mesocosm and 2 microcosm experiments. Mesocosm and the experimental tide cycle, direct heating experiment were analyzed through 3-way ANOVA, whereas the ambient heating was analyzed through a repeated measures ANOVA. $\mathrm{F}$ and $\mathrm{P}$ values are given for each source of variation. ns is not significant.

\begin{tabular}{|c|c|c|c|c|c|c|}
\hline Source of variation & \multicolumn{4}{|c|}{ Variable } & & \\
\hline \multicolumn{7}{|c|}{ Microcosm; ambient heating } \\
\hline & & & \multicolumn{2}{|c|}{ Ammonium (water) } & \multicolumn{2}{|c|}{ Ammonium (sediment) } \\
\hline Time & & & \multicolumn{2}{|l|}{$4.05 / 0.02$} & \multicolumn{2}{|l|}{$9.38 / 0.002$} \\
\hline Treatment & & & \multicolumn{2}{|l|}{$18.32 / 0.0001$} & \multicolumn{2}{|l|}{$29.77 / 0.001$} \\
\hline Time * Treatment & & & \multicolumn{2}{|l|}{$5.43 / 0.001$} & \multicolumn{2}{|l|}{$5.89 / 0.0001$} \\
\hline \multicolumn{7}{|c|}{ Microcosm; Experimental tide cycle, direct heating } \\
\hline & \multicolumn{2}{|l|}{ pH } & \multicolumn{2}{|c|}{ Ammonium (water) } & \multicolumn{2}{|c|}{ Ammonium (sediment) } \\
\hline Tide & \multicolumn{2}{|l|}{$3.9 / 0.005$} & \multicolumn{2}{|l|}{$16.96 / 0.001$} & \multicolumn{2}{|l|}{$11 / 05 / 0.001$} \\
\hline Temperature & \multicolumn{2}{|l|}{$3.4 / 0.07$} & \multicolumn{2}{|l|}{$14.53 / 0.001$} & \multicolumn{2}{|l|}{$17.28 / 0.001$} \\
\hline Clams & \multicolumn{2}{|l|}{ Ns } & \multicolumn{2}{|l|}{$6.62 / 0.013$} & \multicolumn{2}{|l|}{$3.75 / 0.05$} \\
\hline Tide * Temperature & \multicolumn{2}{|l|}{ Ns } & \multicolumn{2}{|l|}{ Ns } & \multicolumn{2}{|l|}{$1.99 / 0.06$} \\
\hline Tide $*$ Clams & \multicolumn{2}{|l|}{ Ns } & \multicolumn{2}{|l|}{ Ns } & \multicolumn{2}{|l|}{ Ns } \\
\hline Temperature * Clams & \multicolumn{2}{|l|}{ 2.93/0.09 } & \multicolumn{2}{|l|}{$4.491 / 0.04$} & \multicolumn{2}{|l|}{$12.6 / 0.001$} \\
\hline Tide * Temperature * Clams & \multicolumn{2}{|l|}{ Ns } & Ns & & Ns & \\
\hline Mesocosm & & & & & & \\
\hline & & $H$ & Ammon & (water) & Ammonit & sediment) \\
\hline & Surface & Sub-surface & Surface & Sub-surface & Surface & Sub-surface \\
\hline Day & $2.6 / 0.08$ & $2.6 / 0.08$ & $8.7 / 0.001$ & $7.0 / 0.003$ & Ns & $11.4 / 0.001$ \\
\hline Tide & Ns & Ns & $14.1 / 0.001$ & $4.3 / 0.001$ & Ns & $31.8 / 0.001$ \\
\hline Treatment & Ns & Ns & Ns & Ns & Ns & Ns \\
\hline Day * Tide & $4.0 / 0.02$ & $4.0 / 0.027$ & $14.6 / 0.001$ & $14.3 / 0.001$ & $11.0 / 0.001$ & $5.7 / 0.005$ \\
\hline Day * Treatment & Ns & Ns & $4.24 / 0.001$ & Ns & Ns & Ns \\
\hline Tide $*$ Treatment & $2.7 / 0.08$ & $2.7 / 0.08$ & $6.08 / 0.001$ & Ns & Ns & Ns \\
\hline Day $*$ Tide $*$ Treatment & Ns & Ns & $2.4 / 0.03$ & Ns & Ns & Ns \\
\hline
\end{tabular}


where sediments were not sterilized both with and without varnish clams maintained a constant sediment ammonium value of ca. $2 \mu \mathrm{g} \cdot \mathrm{g}^{-1}$ throughout the 22 day experiment (Figure 3(a)). By contrast, sediment ammonium was greater in sterilized sediment, both with and without varnish clams, with recovery of ammonium decreasing with room warming (Figure 3(a), Table 1). Significantly greater amounts of ammonium were recovered from the sterilized sediment with varnish clams present on the last two days of the experiment. As with sediment ammonium, ammonium in the overlying water column in non-sterilized treatments was significantly lower as compared to sterilized treatments, with concentration increasing over the 22 days (Figure 3(b), Table 1). Surface water ammonium concentration in the sterilized treatments also increased up to day 15 at which time only the treatment with varnish clams continued to accumulate ammonium (Figure 3(b)). Sorption coefficients decreased in all treatments up until day 11 . Ambient cooling of the room from $20^{\circ} \mathrm{C}$ to $15^{\circ} \mathrm{C}$ correlated to an increase in Kd's for all treatments, notably for the sterilized varnish treatment; warming decreased Kd's, cooling increasing Kd's (that is increasing temperature resulted in greater amounts of ammonium in the water column relative to sediment) (Figure 3(c)).

\subsection{Experimental Tidal Cycle}

Significant differences in $\mathrm{pH}$ occurred at the experimental tidal cycle of RI and RIII, where the heated/with clam treatments had close to a 1.3 fold increase in hydrogen ion as compared to all other treatments (Figure 4(a), Table 1). Ammonium within the sediment was greatest for the heated/with clam treatment with no clear trend with respect to experimental tidal cycle (Figure 4(b), Table 1). Ammonium in the overlying water was dependent both on experimental tidal cycle and treatment (Figure 4(c), Table 1). Greatest amounts of ammonium in overlying water occurred in the heated/with clams treatment and appeared to be dependent on the experimental tidal

a)

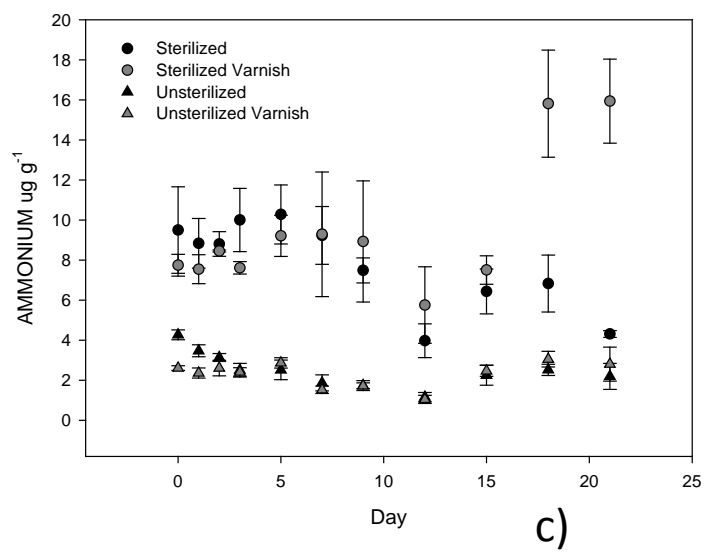

b)

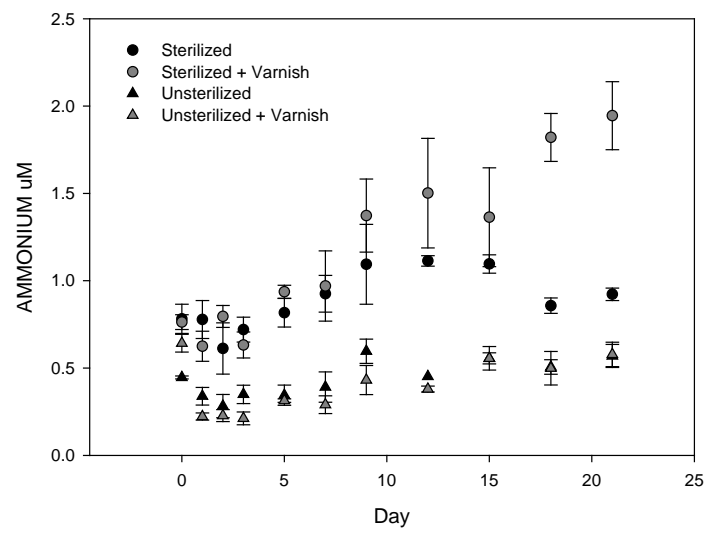

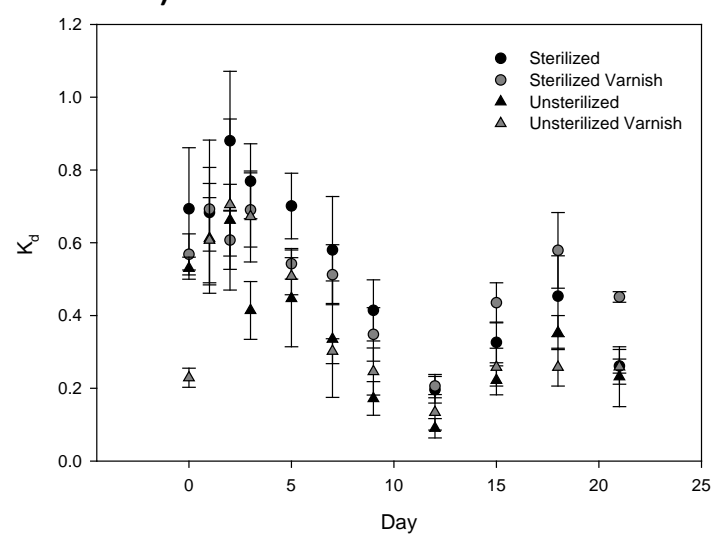

Figure 3. Ambient heating experiments; (a) Sediment ammonium; (b) Overlying water ammonium and (c) Kd (sorption coefficients) for the four treatments over the 22 day sampling period. Values are averages with standard errors (sample sizes reported within methods). 


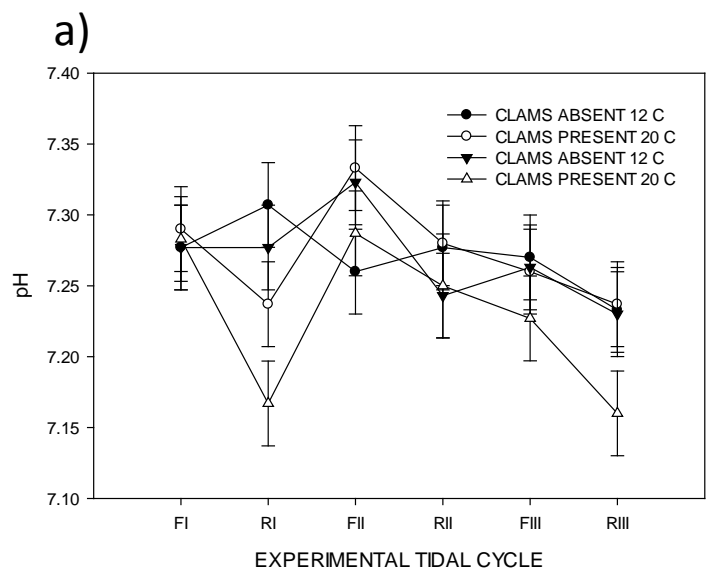

b)

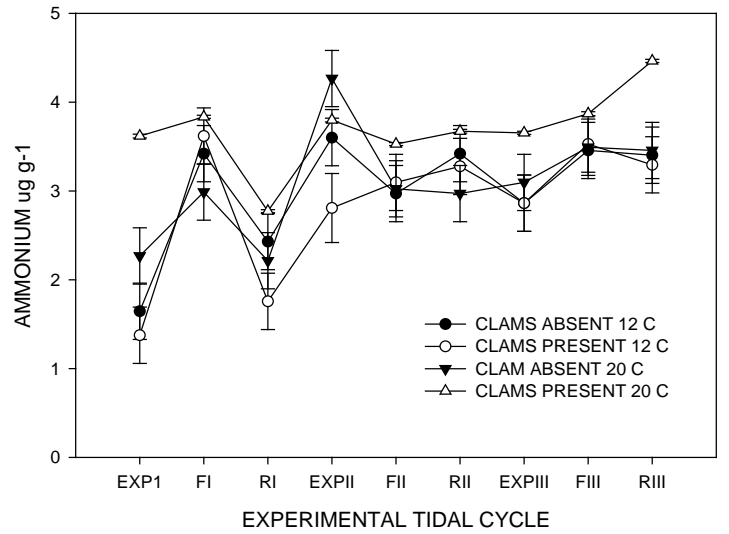

c)

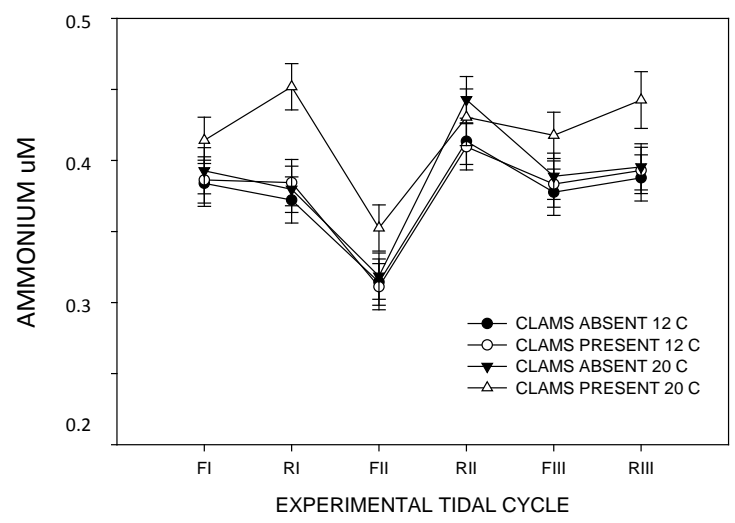

Figure 4. Experimental tidal cycle. (a) Overlying water pH; (b) Sediment ammonium and (c) Overlying water ammonium over the three day experiment. Values are averages with standard errors (sample sizes reported within text).

cycle with greater recovery of ammonium after sediments had been covered with water for 8 hours (i.e., RI, RII and RIII).

\subsection{Mesocosm Experiments}

Day and Tide and the interaction between Day and Tide and Tide and Treatment significantly influenced overlying water $\mathrm{pH}$, ammonium and sediment ammonium both in surficial and sub-surface sediments (Table 1). For both the heated and covered sediments, prior to the rain event, higher pH's were recorded at FI and FII relative to RI and RII suggesting a tidal affect i.e., flood tide buffering the overlying water column (Figure 5(a)). This buffering effect was evident in the sub-surface interstitial waters for FI, heated and exposed. Interstitial ammonium collected from surface sediments demonstrated a strong tidal influence with concentrations peaking during flood tides (FI, FII and FIII, Figure 5(c)). Sub-surface intertidal waters were also tide dependent, notably at FII and FIII (Figure 5(d)). Heated and exposed sediment contained greater amounts of ammonium as compared to covered sediments at FII, otherwise treatment had no effect (Figure 5(d)). Sediment ammonium was affected by both Day and Tide but not treatment for both surface and sub-surface sediments (Figure 5(e) and Figure 5(f), Table 1). As with interstitial waters, higher amounts of extractable ammonium occurred at flood tide (FII), but no clear tidal cycle as with interstitial waters was observed. There was a notable increase in sample variability after the rain event (Figure 5(e) and Figure 5(f)), confounding tidal affects.

\section{Discussion}

\subsection{Microcosms Experiments}

Ammonium is rapidly processed by biological processes. By sterilizing sediments bacterial processes would be 
a)

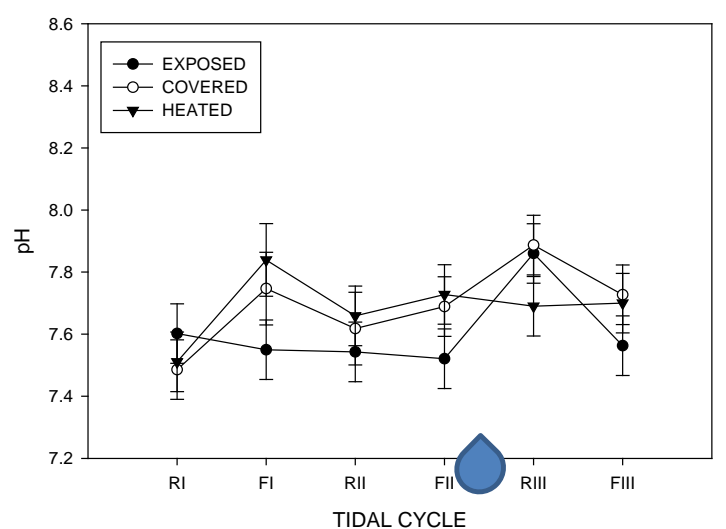

c)

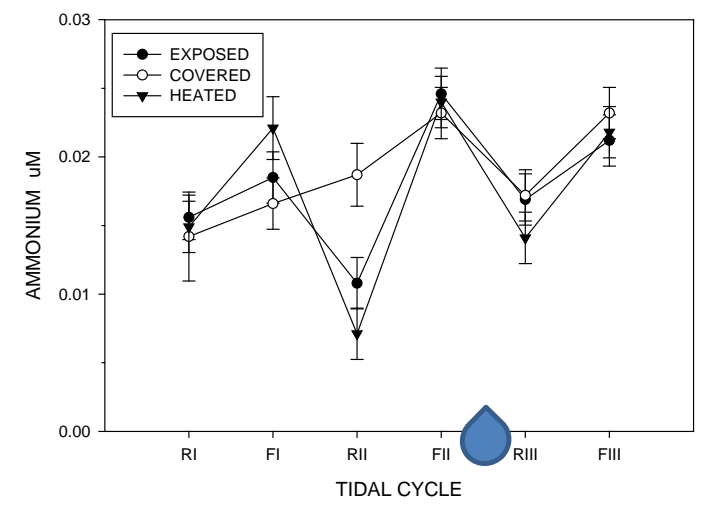

e)

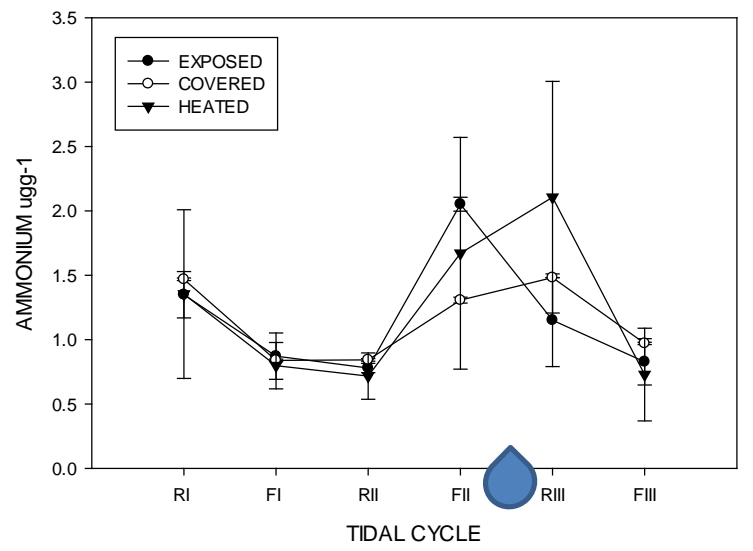

b)

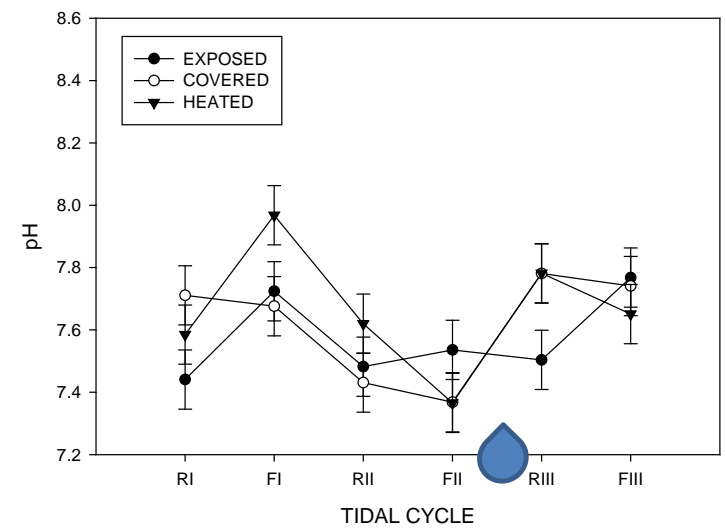

d)

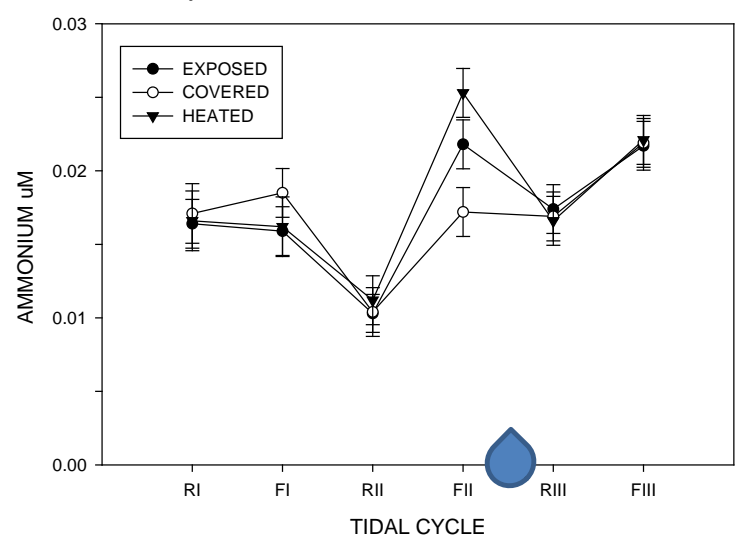

f)

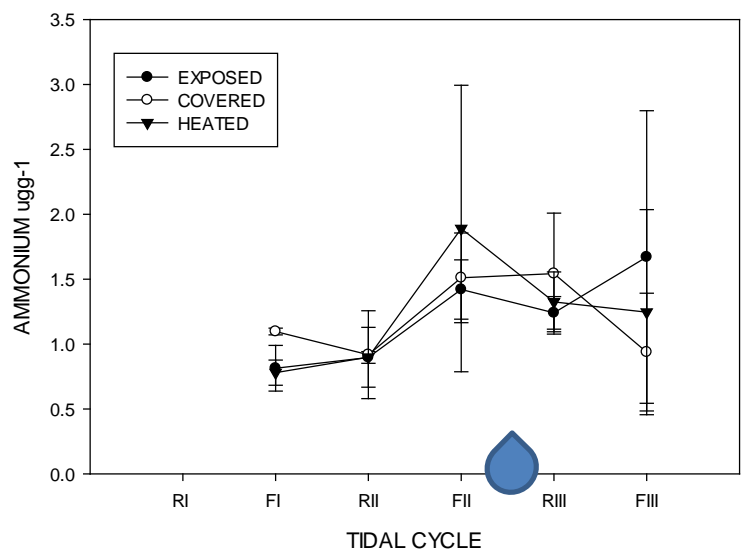

Figure 5. Field mesocosm experiments. (a) Interstitial water pH, 0 - $3 \mathrm{~cm}$; (b) Interstitial water pH, 3 - $6 \mathrm{~cm}$; (c) Interstitial water ammonium, 0 - $3 \mathrm{~cm}$; (d) Interstitial water ammonium, 3 - $6 \mathrm{~cm}$; (e) Sediment ammonium, 0 - $3 \mathrm{~cm}$; (f) Sediment ammonium, $3-6 \mathrm{~cm}$. Values are averages with standard errors (sample sizes reported with in text). The rain event is indicated with a blue rain drop between FII and RIII.

prevented or at least reduced enabling an evaluation of the amounts of ammonium contributed by bivalves to the intertidal environment. Ambient warming of room temperature increased the amounts of ammonium within surface water for all treatments but notably for those treatments with sterilized sediments and varnish clams. With 
increasing temperatures, greater concentrations of ammonium in the water column relative to sediment were observed (e.g., decreasing Kd values). Experimental tidal experiments with and without bivalves also demonstrated the affect of warming with greater amounts of ammonium recovered from both sediments and water under the heated/with clam treatments as compared to heated/without clams.

Studies on the influence of temperature on ammonium excretion rates in bivalves indicate that rates generally increase with increasing temperature. For example Manila clam excretion rates were found to increase with increasing temperatures [17] in both large and small (36 and $26 \mathrm{~mm}$ respectively) clams [18]. Excretion rates of Dreissena polymorpha acclimated to $20^{\circ} \mathrm{C}, 24^{\circ} \mathrm{C}, 28^{\circ} \mathrm{C}$ and $32^{\circ} \mathrm{C}$ for 30 days were 4.9 times greater at $32^{\circ} \mathrm{C}$ as compared to bivalves acclimatized to $20^{\circ} \mathrm{C}$ [19]. By contrast, excretion rates of Ruditapes decussatus (L.) acclimated for 48 hours to a range of selected temperatures $\left(20^{\circ} \mathrm{C}-35^{\circ} \mathrm{C}\right)$ were temperature independent in the experimental range which was attributed to seasonal thermal acclimation to environmental fluctuating temperatures [20].

The experimental tidal cycle also appeared to affect $\mathrm{pH}$ with a decrease observed in the heated/with clams microcosms. Oxygen consumption rates in clams increase with temperature up until $25^{\circ} \mathrm{C}$ [18] which results in a greater release of $\mathrm{CO}_{2}$ that can react with seawater to produce carbonic acid and hence lower overlying water $\mathrm{pH}$ [21].

\subsection{Mesocosm Studies}

While we were successful in obtaining a temperature difference between exposed/heated and covered mesocosms, treatment (temperature) did not appear to affect ammonium in either sub-surface or surface sediments. There was one exception however, with the greatest amounts of aqueous ammonium occurring at a sub-surface depth at FII, preceding the rain event and just after intense heating. Fluxes of ammonium from both sandy and muddy sediments in a shallow coastal lagoon have been shown to be sensitive to differences in temperature, with greater fluxes noted during summer as compared to cooler seasons [22]. Greater diffusive fluxes of ammonium from surface sediments of the southern Baltic Sea in late summer when water temperature has been the warmest have also been reported [23].

Tide had a significant affect with flood tides generally containing greater amounts of ammonium within sediment interstitial waters as compared to ebb tides. Studies on the effect of tidal range on the flushing of ammonium from intertidal sediments of the Tagus estuary, Portugal have found a clear pattern with considerable quantities of ammonium being exported from the sediment to the water column just at the beginning of inundation [24]. Under experimental laboratory conditions it has been demonstrated that flood tides promote the efflux of ammonium into overlying waters with this flux an important source of nutrients to overlying waters during the long-term exposure of sediment during spring and neap tides [25]. Finally, it has also been shown that seawater which has entered sediment during flood tides contain higher concentrations of nutrients within sediment interstitial waters as compared to seawater [26].

Interstitial water $\mathrm{pH}$ was also influenced by tidal activity tending to be higher on the flood rather than ebb tides. However, the rain event that occurred between FII and RIII may have obscured a more definitive relationship. As rain water is slightly acidic ( $\mathrm{pH}$ of 5.4), it would contribute to interstitial water acidity when the intertidal is exposed, possibly resulting in the lower than expected $\mathrm{pH}$ recorded at FII for sub-surface sediments and to a lesser extent for surface sediments. In addition to rain events, intertidal $\mathrm{pH}$ is subject to a number of environmental factors that can add to its variability including temperature, photosynthesis and animal respiration. Respiration during ebb tides would result in an accumulation of $\mathrm{CO}_{2}$ over the period of exposure which could then reduce interstitial water $\mathrm{pH}$ as seen in RI and RII at $0-3 \mathrm{~cm}$ depth as well at RI and RII at $3-6 \mathrm{~cm}$ depth. In both cases, on the flood tide FI, pH increased suggesting that incoming seawater with a $\mathrm{pH}$ of 7.6 was acting as a buffer.

\subsection{Integration of Lab and Field Studies}

On the west coast of BC the dominant intertidal bivalves are now the two non-indigenous species, the Manila and varnish clam. Their numbers can occur at densities 4 to 8 times greater than that of the indigenous species the native little neck which is confamilial to the Manila and varnish clam [6] [8]. Hence, the two non-indigenous species have the potential to be key drivers mediating biogeochemical cycles within the intertidal. Integrating the results of the microcosm and fields studies we suggest that high densities of the Manila and varnish clam will lead to greater amounts of ammonium released to the intertidal with this amount increasing with tempera- 
ture. Accumulation of intertidal ammonium will then be discharged to coastal seas as a "pulse" on flood tides. As a result of increased respiration rates due to higher densities of bivalves, interstitial waters will also increase in acidity.

A recent constructed a nitrogen budget of the Strait of Georgia, a semi-enclosed coastal sea of the west coast of BC where high numbers of Manila and varnish clams occur found that the overall anthropogenic contribution of particulate nitrogen and dissolved inorganic nitrogen to the Strait of Georgia was minimal relative to natural sources, although anthropogenic nitrogen sources such as wastewater outfalls may have significant local effects [27]. Baynes Sound which is within the Strait of Georgia, is a major shellfish farming region producing over 50\% of British Columbia's oysters and Manila clams [4]. The city of Courtney-Comox is also located on Baynes Sound with the local river and estuary which is highly eutrophic closed to shellfish farming due to high levels of fecal coliforms. The combined contributions of ammonium from the high density of farmed Manila clams as well as human inputs could lead to the eutrophication of this region. Eutrophication as well as warming temperatures has been linked to the occurrence of harmful algae blooms (HAB) [28] and the increased fluxes of ammonium from the intertidal may serve to facilitate these blooms within regions where anthropogenic inputs are already occurring.

There are large gaps in our understanding of the impacts of ocean acidification which includes the natural variability of $\mathrm{pH}$ and the interactions of changes in other environmental stressors such as increased temperature [7]. To contribute to reducing these data gaps our findings suggest that intertidal $\mathrm{pH}$ will also be affected by the increased numbers of bivalves with increased respiration contributing to acidity within the sediment interstitial water through increased $\mathrm{CO}_{2}$ production. This process will also be facilitated within a warming environment. The biological significance of this decrease in $\mathrm{pH}$ and whether it will contribute to ocean acidification within coastal BC in general, however, is not known. The northwest coast of North America is particularly vulnerable to ocean acidification due to regional factors such as coastal upwelling which brings offshore waters rich in carbon dioxide and low in $\mathrm{pH}$ [29]. Impacts of ocean acidification are already been felt by the shellfish industry with large die offs of oyster seed being attributed to low $\mathrm{pH}$ of coastal waters [30]. Given the potential for high densities of the non-indigenous Manila and varnish clam to increase flux of ammonium and $\mathrm{pH}$ to shallow coastal seas, it would seem prudent that where possible, populations are kept at low numbers to ensure that intertidal ammonium fluxes and $\mathrm{pH}$ are not influenced by their presence.

\section{Acknowledgements}

The field assistance of Jodie McKormick is gratefully appreciated. LB gratefully acknowledges funding support from a NSERC Discovery grant.

\section{References}

[1] Jickell, T.D. (1998) Nutrient Biogeochemistry of the Coastal Zone. Science, 281, 217-222. http://dx.doi.org/10.1126/science.281.5374.217

[2] Sandwell, D.R., Pilditch, C.A. and Lohrer, A.M. (2009) Density Dependent Effects of an Infaunal Suspension-Feeding Bivalve (Austrovenus stutchburyi) on Sandflat Nutrient Fluxes and Microphytobenthic Productivity. Journal of Experimental Marine Biology and Ecology, 373, 16-25. http://dx.doi.org/10.1016/j.jembe.2009.02.015

[3] Dame, R.F. (1996) Ecology of Marine Bivalves, an Ecosystem Approach. CRC Press, Boca Raton, 254 p.

[4] Bendell, L.I. (2013) Evidence for Declines in the Native Leukoma staminea as a Result of the Intentional Introduction of the Non-Native Venerupis philippinarum in Coastal British Columbia, Canada. Estuaries and Coasts, 37, 369-380. http://dx.doi.org/10.1007/s12237-013-9677-1

[5] Dudas, S.E. and Dower, J.F. (2006) Reproductive Ecology and Dispersal Potential of Varnish Clam, Nuttallia obscurata, a Recent Invader in the Northeast Pacific Ocean. Marine Ecology Progress Series, 320, 195-205. http://dx.doi.org/10.3354/meps320195

[6] Chan, K. and Bendell, L.I. (2013) Potential Effects of an Invasive Bivalve, Nuttallia obscurata, on Biogeochemical Cycling in the Intertidal. Journal of Experimental Marine Biology and Ecology, 444, 66-72. http://dx.doi.org/10.1016/j.jembe.2013.03.013

[7] Gazeau, F., Parker, L.M. and Commeau, S. (2013) Impacts of Ocean Acidification on Marine Shelled Molluscs. Marine Biology, 160, 2207-2245. http://dx.doi.org/10.1007/s00227-013-2219-3

[8] Chan, K. (2012) Potential Effects of an Invasive Bivalve, Nuttallia obscurata, on Biogeochemical Cycling in the Intertidal. M.Sc. Thesis, Simon Fraser University, Burnaby. 
[9] Trevors, J.T. (1996) Sterilization and Inhibition of Microbial Activity in Soil. Journal of Microbiology Methods, 26, 53-59. http://dx.doi.org/10.1007/s00227-013-2219-3

[10] Harrison, P.J. and Berges, J.A. (2005) Marine Culture Media. In: Andersen, R.A., Ed., Algal Culturing Techniques, Elseviser, Burlington, 25 p.

[11] Newell, R.I.E., Cornwell, J.C. and Owens, M. (2002) Influence of Experimental Bivalve Biodeposition and Microphytobenthos on Nitrogen Dynamics: A Laboratory Study. Limnology and Oceanography, 47, 1367-1379. http://dx.doi.org/10.4319/lo.2002.47.5.1367

[12] Nollet, L.M.L. (2000) Handbook of Water Analysis. Marcel Dekker, New York.

[13] Bendell, L.I., Duckham, C., L’Espérance, T. and Whiteley, J.A. (2010) Changes in Geochemical Foreshore Attributes as a Consequence of Intertidal Shellfish Aquaculture: A Case Study. Marine Ecology Progress Series, 404, 91-108. http://dx.doi.org/10.3354/meps08487

[14] Hursthouse, A.S., Iqbal, P.P. and Denman, R. (1993) Sampling Interstitial Waters from Intertidal Sediments: An Inexpensive Device to Overcome an Expensive Problem? Analyst, 118, 1461-1462. http://dx.doi.org/10.1039/an9931801461

[15] Keeney, D.R. and Nelson, D.W. (1982) Nitrogen-Organic Forms. In: Page, A.L., Ed., Methods of Soil Analysis Part 2: Chemical and Microbiological Properties, 2nd Edition, Soil Science of America, Madison, 674-682.

[16] Gosling, E. (2003) Bivalve Molluscs: Biology, Ecology and Culture. Fishing New Books, Blackwell Publishing, 443 p. http://dx.doi.org/10.1002/9780470995532

[17] Zhu, S., Saucier, B., Durfey, J., Chen, S. and Dewey, B. (1999) Waste Excretion Characteristics of Manila Clams (Tapes philippinarum) under Different Temperature Conditions. Aquacultural Engineering, 20, 231-244. http://dx.doi.org/10.1016/S0144-8609(99)00015-1

[18] Han, K.N., Lee, S.W. and Wang, S.Y. (2008) The Effect of Temperature on the Energy Budget of the Manila Clam, Ruditapes philippinarum. Aquaculture International, 16, 143-152. http://dx.doi.org/10.1007/s10499-007-9133-y

[19] Aldridge, D.W., Payne, B.S. and Miller, A.C. (1995) Oxygen Consumption, Nitrogenous Excretion, and Filtration Rates of Dreissena polymorpha at Acclimation Temperatures between $20^{\circ} \mathrm{C}$ and $32^{\circ} \mathrm{C}$. Canadian Journal of Fish and Aquatic Sciences, 52, 1761-1767. http://dx.doi.org/10.1139/f95-768

[20] Sobral, P. and Widdows, J. (1997) Effects of Elevated Temperatures on the Scope for Growth and Resistance to Air Exposure of the Clam Ruditapes decussats (L.), from Southern Portugal. Scientia Marina, 61, 163-171.

[21] Lükewille, A. and Alewell, C. (2008) Acidification. In: Jorgensen, S.E. and Fath, B., Eds., Encyclopedia of Ecology, Elsevier, Amsterdam, 23-31.

[22] Nizzoli, D., Bartoli, M. and Viaroli, P. (2007) Oxygen and Ammonium Dynamics during a Farming Cycling of the Bivalve Tapes philippinarum. Hydrobiologia, 587, 25-36. http://dx.doi.org/10.1007/s10750-007-0683-9

[23] Maksymowska-Brossard, D. and Piekarek-Jankowska, H. (2001) Seasonal Variability of Benthic Ammonium Release in the Surface Sediments of the Gulf of Gdańsk (Southern Baltic Sea). Oceanologia, 43, 113-136.

[24] Cabrtia, M.T., Fernanod, C. and Vale, C. (1998) The Effect of Tidal Range on the Flushing of Ammonium from Intertidal Sediments of the Tagus Estuary, Portugal. Oceanologica Acta, 22, 291-302. http://dx.doi.org/10.1016/S0399-1784(99)80053-X

[25] Hou, L.J., Liu, M., Xu, S.Y., Ou, D.N., Lu, J.J., Yu, J., Cheng, S.B. and Yang, Y. (2005) The Effects of Semi-Lunar Spring and Neap Tidal Change on Nutrients Cycling in the Intertidal Sediments of the Yangtze Estuary. Environmental Geology, 48, 255-264. http://dx.doi.org/10.1007/s00254-005-1304-4

[26] Anschutz, P., Smith, T., Mouret, A., Deborde, J., Bujan, S., Poirier, D. and Lecroart, P. (2009) Tidal Sands as Biogeochemical Reactors. Estuarine Coastal and Shelf Science, 84, 84-90. http://dx.doi.org/10.1016/j.ecss.2009.06.015

[27] Sutton, J.N., Johannessen, S.C. and Macdonald, R.W. (2013) A Nitrogen Budget for the Strait of Georgia, British Columbia. Biogeosciences Discussion, 10, 7135-7169. http://dx.doi.org/10.5194/bgd-10-7135-2013

[28] Anderson, D.M. Burkholder, J.M., Cochlan, W.P., Glibert, P.M., Gobler, C.J., Heil, C.A., Kudela, R.M., Parsons, M.L., Rense, J.E., Townsend, D.W., Trainer, V.L. and Vargo, G.A. (2008) Harmful Algal Blooms and Eutrophication: Examining Linkages from Selected Coastal Regions of the United States. Harmful Algae, 8, 39-53. http://dx.doi.org/10.1016/j.hal.2008.08.017

[29] Adelsman, H. and Binder, L.W., Eds., Washington State Blue Ribbon Panel on Ocean Acidification (2012) Ocean Acidification: From Knowledge to Action, Washington State's Strategic Response. Washington Department of Ecology, Olympia, Washington. Publication No. 12-01-015.

[30] Waldbusser, G.G., Brunner, E.L., Haley, B.A., Hales, B., Langdon, C.J. and Prahl, F.G. (2013) A Developmental and Energetic Basis Linking Larval Oyster Shell Formation to Ocean Acidification. Geophysical Research Letters, 40, 2171-2176. http://dx.doi.org/10.1002/grl.50449 
Scientific Research Publishing (SCIRP) is one of the largest Open Access journal publishers. It is currently publishing more than 200 open access, online, peer-reviewed journals covering a wide range of academic disciplines. SCIRP serves the worldwide academic communities and contributes to the progress and application of science with its publication.

Other selected journals from SCIRP are listed as below. Submit your manuscript to us via either submit@scirp.org or Online Submission Portal.
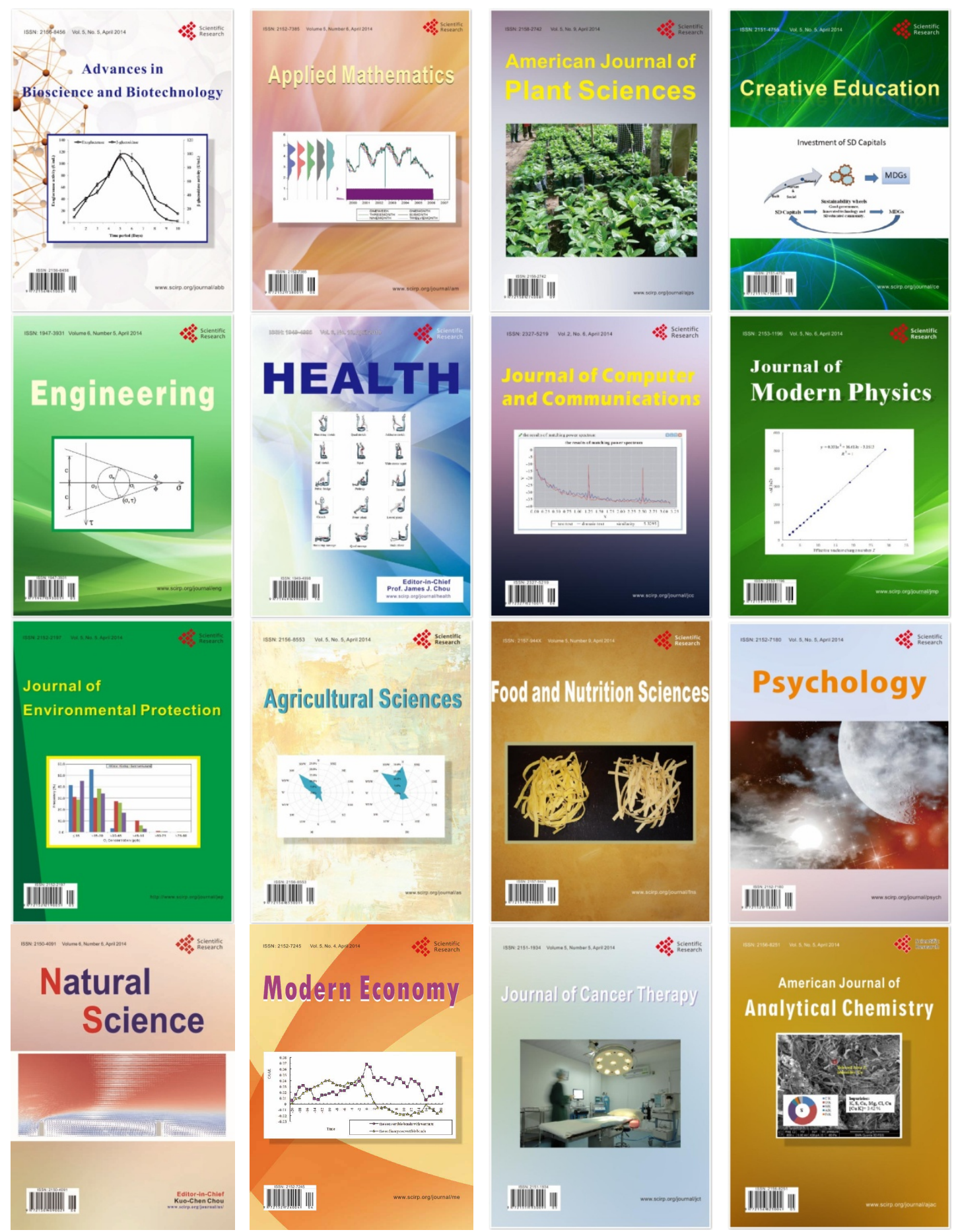